зонний, циклічний і випадковий компоненти. Результати моделювання дозволили встановити закономірності зміни цін акцій трьох провідних підприємств, які представляють будівельний, промисловий і банківський сектори ліванської економіки. Виміряно тривалість і глибину малих циклів у динамічних рядах досліджуваних показників. Встановлено, що глибина циклічних коливань збільшується при зниженні цін на акції будівельних і промислових підприємств Лівану під впливом як економічних, так і політичних процесів. Водночас циклічність в цінах на акції банківського сектору країни менш виражена і переважно визначається змінами, що відбувалися в економіці

Ключові слова: фондовий ринок, статистичний аналіз, декомпозиція часових рядів, малі иикли, компоненти часових рядів, економіка Лівану.

Bibliographic description for quoting:

Agabekova, N. V., \& Abdo, A. N. A. (2021). Economic and Statistical Analysis of Stock Market Performance in Lebanon. Statystyka Ukrainy - Statistics of Ukraine, 1, 75-84. Doi: 10.31767/su.1(92)2021.01.08.

Бібліографічний опис для цитування:

Агабекова Н. В., Абдо А. Н. А. Економіко-статистичний аналіз індикаторів фондового ринку Лівану (публікується англійською мовою). Статистика Украӥни. 2021. № 1. С. 75-84.

Doi: 10.31767/su.1(92)2021.01.09.

\title{
ШІановні читачі!
}

Ви маєте можливість оформити редакційну передплату за реквізитами:

Одержувач платежу: Національна академія статистики, обліку та аудиту

Код ЄДРПОУ 04837462 ,

Рахунок одержувача UA923206490000026000052638100, МФО 320649

Установа банку: ПАТ «ПриватБанк» м. Києва.

Вид платежу: за журнал «Статистика України».

Вартість редакційної передплати: 150 грн за номер.

Прізвище та адресу доставки повідомляйте на e-mail: statukraine_edit@ukr.net

або за телефоном: (044) 486-36-48. 
УДК 311.21:314-049.5(476)

JEL Classification: C15, J11, J18

Doi: 10.31767/su.1(92)2021.01.09

\section{E. E. Sharilova,}

PhD in Economics, Associate Professor,

Associate Professor of the Statistics Department,

Educational Institution "Belarus State Economic University" (Minsk, Belarus),

E-mail: sharilovaee@mail.ru

ORCID: https://orcid.org/0000-0002-4862-3624

\section{A Comprehensive Assessment of the Demographic Security of the Republic of Belarus}

Security is a necessary component of the life of individuals and society as a whole. One of the most important components of the national security is demographic security, which achievement in the Republic of Belarus means the neutralization of threats such as depopulation, population ageing, degradation of the family institute and unregulated migration processes.

The article presents a methodology for a comprehensive statistical assessment of the demographic security of the Republic of Belarus for 2000-2019, based on of the dualistic approach to the interpretation of this concept, proposed by the author, namely: real and potential demographic security. The real demographic security is the degree of protection from demographic threats in the current social circumstances, which is largely determined by the compliance of government policy with demographic realities.

The proposed methodology for a comprehensive assessment of demographic security includes five consecutive phases: formulating a definition of "demographic security", identifying demographic threats, building a set of indicators for a comprehensive statistical assessment of demographic security, assessing the effect of demographic threats (general and real), and, finally, assessing the degree of protection from demographic threats (real demographic security).

The structural components of the overall strength of demographic threats are the degrees of real demographic security and the real strength of the threats. The following trend in these values was observed in the Republic of Belarus in 2000-2019: an increase in the degree of real demographic security in parallel with a decrease in the degree of real combined strength of threats in 2015 compared to 2000, giving way to a decrease in the first indicator and an increase in the second one in 2019. It follows that the achievements of the Republic of Belarus in demographic security were short-lived. For a systemic change in the negative trends, it is necessary to form a favorable demographic situation through the active use of educational and propagandist measures. policy.

Key words: demographic security, demographic threat, indicator, demographic conjuncture, demographic

Introduction. Security is a necessary component in the life activity of individuals, with the second rank in the Maslow's hierarchy of needs. The notion of national security occurs at macroeconomic level, to reflect the maximally possible combined level of protection from existing threats in various domains, e. g. economic, political, social, environmental, informational, and in the most inertial domain of demography.

A review of literary sources demonstrates that the post-soviet society is greatly concerned with the methodological problem of demographic security assessment, due to the significant and more often adverse impact of the demographic component on the development of regions. The geographic location of research authors publishing in the field includes the Republic Belarus [1; 2], the Russian Federation [3; 4], Ukraine [5], Kazakhstan [6], Uzbekistan [7], and others.

(C) E. E. Sharilova, 2021
Demographers, economists and sociologists propose various approaches to the assessment of demographic security, e. g.: (i) using one summary indicator; (ii) constructing a set of indicators; (iii) constructing an integral indicator by various methods (multivariate mean, principal component analysis, ranking, scoring system, etc.).

Each approach has its advantages and weaknesses, but neither of them has been assigned the status of commonly accepted one. Hence, the search for "ideal" indicator for the demographic security assessment is going on. The applicability of statistics methods for this purpose is not questioned, but, as rightly observed by the authors of the collective monograph "Methodology for the analysis of demographic security and migration of the population", in spite of all the power of statistical tools, "...clear and unbiased interpretation of the cognition object" is required [3, p. 6]. So, the notion of "demographic security" needs to be strictly defined in the context of this study. 
Research results and their analysis. Researchers tend to interpret demographic security as the state of security. They include L. Shakhotska, N. Privalova [2, p. 17], S. Soboleva, O. Chudaeva [4, p. 149], authors of the above mentioned monograph [3, p. 15] and others. This approach was also used in the definition of this notion, given in the Law of the Republic of Belarus "Demographic security": Demographic security is the state of protection of the socio-economic development of the government and society from demographic threats, which ensures the development of the Republic of Belarus in compliance with its national demographic interests" [8].

We believe that the word combination "the state of protection" has an explicitly positive meaning by making impression of the total protection from demographic threats. A definition like this can create an illusion of some demographic ideal rather than the reality. We think that erroneous treatment or misconception of the above notion can be eliminated by distinguishing between the potential demographic security and the real one.

In view of the above, the definition of demographic security as the state of protection from demographic threats should be considered as the potential demographic security, whereas the state resulting from interactions (collisions) of demographic threats and the system of protection from them, operating within the stablished demographic conjuncture, should be defined as the real demographic security.

The definition of the real demographic security, proposed by the author, requires an explanation. The system for protection from demographic threats is a system created by the government, which includes elaboration and adoption of normative and legal acts aiming to minimize the effect of demographic threats, inform the population about existing demographic problems and their consequences, financing of research in demographic field, etc. As regards demographic conjuncture, it refers to a combination of specific components of demographic and social nature, prevailing in a given period and capable to either enhance or reduce the efficiency of the government's protection system. These components can include attitudes to marriage at family or community level, perceptions of the optimal age for marriage and birth of children, average social norm of the number of children in a family, reproductive plans of the population (average expected number of children), age structure of reproductive groups, migration activity of the population, patterns of healthy way of life among the population, etc. The demographic conjuncture has effects for the intensity of demographic processes. Hence, a while favorable demographic conjuncture may enhance the efficiency of implemented measures, an unfavorable one may reduce it.

Summing up the theoretical part of the studied problem, it needs to be noted that the real demographic security refers to the degree of protection from demographic threats in the prevailing social conditions, which is to a great extent conditional on the compliance of government policy with demographic realities. When the protection degree makes 1 , it may be said that the potential demographic security is achieved. The potential demographic security is, therefore, an ideal to be sought by the real demographic security, whereas the real demographic security refers to the realized potential security.

Once the meaning of the studied notion is clarified, we can proceed with constructing an algorithm for implementation of the method for a comprehensive assessment of demographic security (Figure 1, author's development).

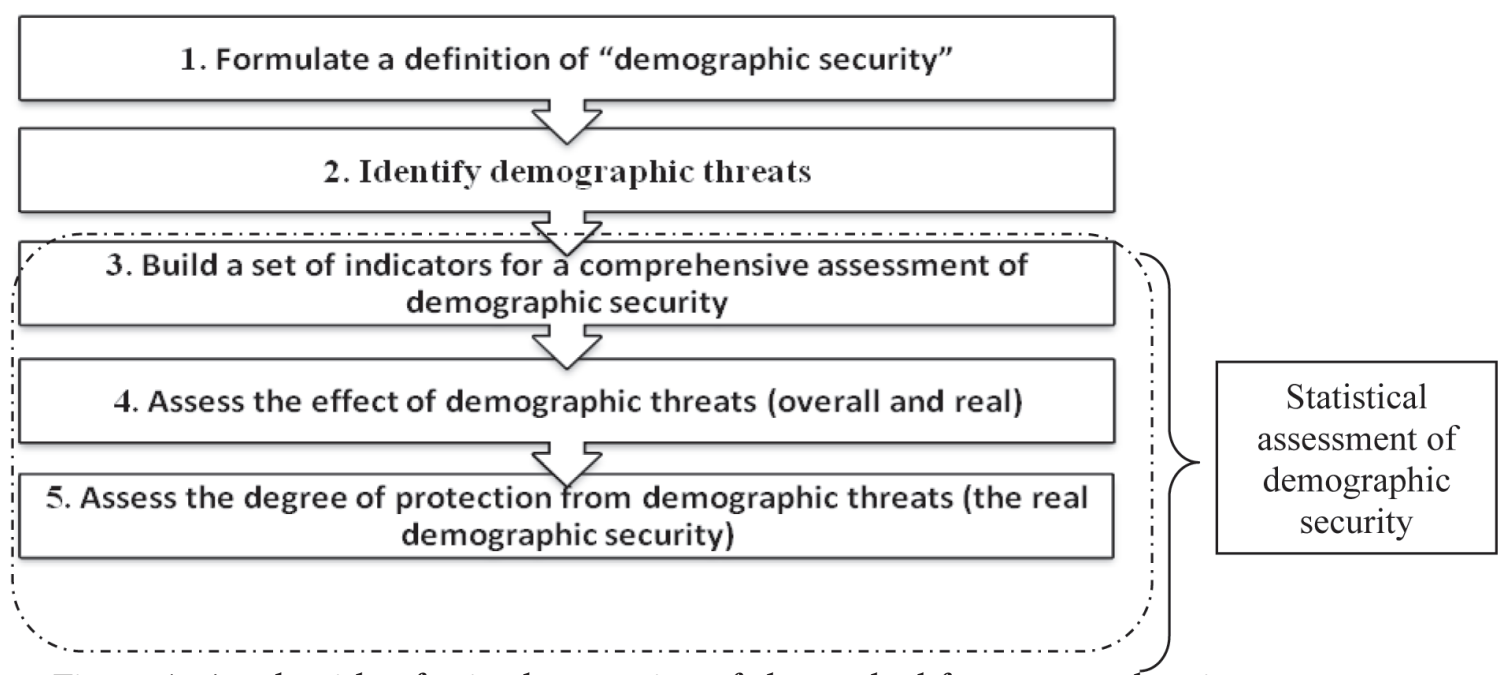

Figure 1. An algorithm for implementation of the method for a comprehensive assessment of demographic security

Each of the six phases is discussed below.

1 phase. Formulate a definition of "demographic security". This phase of the method is described earlier.
It finishes with the specification of the above notion by introducing two clarified definitions, i. e. "real demographic security" and "potential demographic 
security", to allow for a subsequent statistical assessment of the effect from demographic threats and the degree of protection.

2 phase. Identify demographic threats. The second phase of the method can be implemented by two ways: (i) learning about legal acts on demographic security regulation; (ii) individual analysis of the demographic situation in the country, to identify pressure points. The Republic of Belarus was the first in the Commonwealth of Independent Nations to adopt the Law "Demographic

Statistical indicators for a comprehensive assessment of demographic security

\begin{tabular}{|l|l|}
\hline \multicolumn{1}{|c|}{ Demographic threat } & \multicolumn{1}{c|}{ Statistical indicators } \\
\hline 1. Depopulation & $\begin{array}{l}\text { 1.1. Total fertility rate } \\
\text { 1.2. Depopulation rate } \\
\text { 1.3. Mortality rate of the working-age population }\end{array}$ \\
\hline 2. Ageing of the population & $\begin{array}{l}\text { 2.1. Old age ratio } \\
\text { 2.2. Generation ratio (proportion between the number of persons aged 60 or } \\
\text { more and the number of ones aged 0-14) }\end{array}$ \\
\hline $\begin{array}{l}\text { 3. Degradation of the family } \\
\text { institute }\end{array}$ & $\begin{array}{l}\text { 3.1. Instability rate of marriages } \\
\text { 3.2. Share of births with women that have never been in registered marriage, in } \\
\text { the total births }\end{array}$ \\
\hline $\begin{array}{l}\text { 4. Unregulated migration } \\
\text { processes }\end{array}$ & 4.1. Net immigration \\
\hline
\end{tabular}

The benchmarks for each of the indicators are given in Table 2. It should be noted that a number of targeted figures are fixed in the State Program "Public Health and Demographic Security of the Republic of
Belarus for 2016-2020" [9]. These target figures are used for standardizing the estimate for the studied period of $2000-2019$.

Benchmarks of the statistical indicators

\begin{tabular}{|c|c|c|}
\hline Indicator & Benchmark & Justification \\
\hline \multicolumn{3}{|c|}{ Depopulation } \\
\hline Total fertility rate & $\begin{array}{l}1.75 \text { births per } \\
\text { woman }\end{array}$ & A target figure fixed as part of Program [9] \\
\hline Depopulation rate & 1.0 & $\begin{array}{l}\text { This value is reached when the death ratio is equal to the } \\
\text { birth ratio }\end{array}$ \\
\hline $\begin{array}{l}\text { Mortality rate of the working-age } \\
\text { population }\end{array}$ & $3.8 \%$ & A target figure fixed as part of Program [9] \\
\hline \multicolumn{3}{|c|}{ Ageing of the population } \\
\hline Old age ratio & $18 \%$ & $\begin{array}{l}\text { By G. Boge-Garnier and E. Rosset scale, this value is } \\
\text { the lower margin of the very high level of demographic } \\
\text { ageing }[10, \text { p. 113] }\end{array}$ \\
\hline Generation ratio & 1.0 & $\begin{array}{l}\text { This value is reached when the number of old generation } \\
(60 \text { years or more }) \text { equals the number of children } \\
(0-14 \text { years })\end{array}$ \\
\hline \multicolumn{3}{|c|}{ Degradation of the family institute } \\
\hline Instability rate of marriages & 0.35 & The level of 1990 (pre-crisis year) \\
\hline $\begin{array}{l}\text { Share of births with women that } \\
\text { have never been in registered } \\
\text { marriage }\end{array}$ & $8.5 \%$ & The level of 1990 (pre-crisis year) \\
\hline \multicolumn{3}{|c|}{ Unregulated migration processes } \\
\hline Net immigration & 14,000 & $\begin{array}{l}\text { A target figure fixed in the Program is } 70,000 \text { persons for } \\
\text { the period of } 2016-2020 \text { [9] }\end{array}$ \\
\hline
\end{tabular}

It should be noted that benchmarks can be fixed with reference to target figures set in state programs for socio-economic and demographic development, Sustainable Development Goals, maximal, minimal or average levels of selected indicators for Belarussian regions or economically development countries, etc.

The indicators given in Table 1 are heterogeneous in content, with some of them targeted upwards 
and others, instead, targeted downwards. It is, therefore, seems to be useful to break them into two groups: stimulators and de-stimulators. Stimulators include total fertility rate and net migration, and destimulators cover all the other indicators.

The strength of threats and the degree of protection from them are assessed in a way allowing to combine phases 4 and 5 of the proposed method.

Phases 4 and 5. Assessing the strength of demographic threat and the degree of protection. The overall strength of a threat can be measured in relation to certain reference points, which can be minimal, maximal or benchmark figures. But the threat's blow is partially compensated by government policy measures that can be either enhanced or weakened under the pressure of the prevailing demographic conjuncture. Hence, the overall strength of a threat can be structurally presented by two components: the real strength of a demographic threat and its compensated strength. The latter component will constitute the degree of protection.

Thebenchmark figureand theworstfigureobtained over the studied period or on a certain territory are proposed as reference points in implementing 4 and 5 phases of the method. The minimal value $\left(\hat{E}^{\mathrm{min}}\right)$ will be the worst figure for stimulators, and the imaximal value $\left(\hat{E}^{\max }\right)$ will be the worst one for de-stimulators. The proposed approach is illustrated in Figure 2.

The degree of real strength of a demographic threat with account for the existing protection

system and the prevailing demographic conjuncture - the real demographic security
The degree of protection from a demographic threat with account for the existing protection system and the prevailing demographic conjuncture

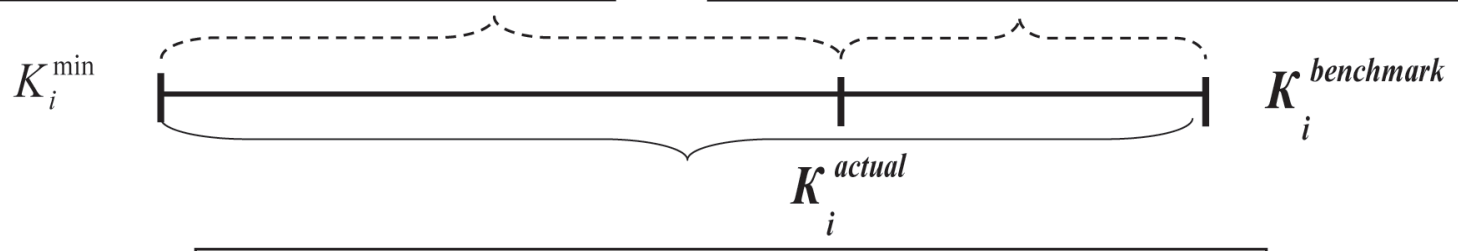

The overall strength of a demographic threat within the observed minimum and fixed benchmark value

a) Indicators-stimulators

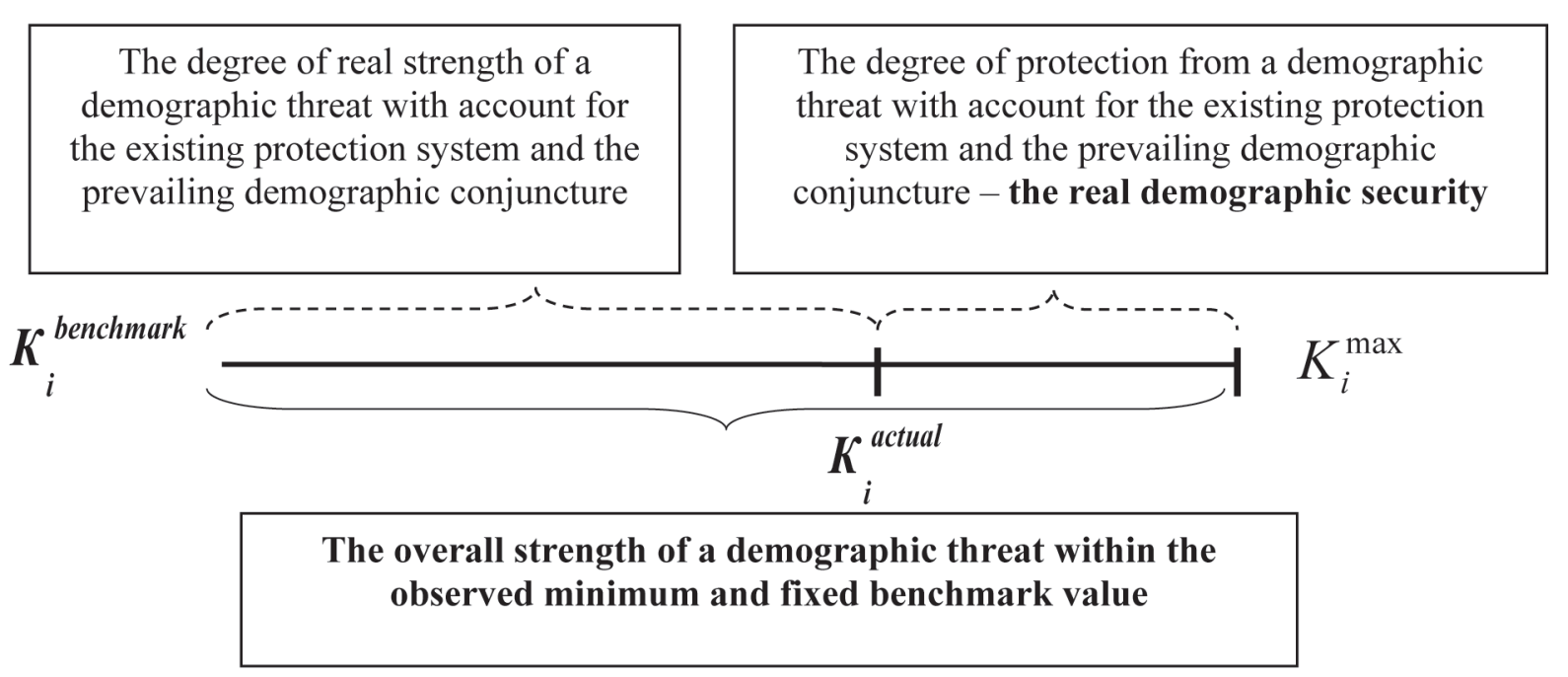

\section{b) Indicators-de-stimulators}

Figure 2. Structural components of the overall strength of a demographic threat by indicator $K_{i}$

The protection system built by the government is designed in way to approximate the real value to the benchmark one, considering the prevailing demographic conjuncture.
It is proposed to determine the structural components forming the overall strength of a demographic threat by indicator $K_{i}$ by use of the linear scaling method with some adjustments, 
namely: (i) calculation formulas are differentiated by indicator content (stimulators and de-stimulators); (ii) the benchmark value is taken as the best one; (iii) the choice of the worst value is determined by the indicator context (see above). The calculation formulas are given in Table 3 .

The calculation formulas for assessing structural components forming of the overall strength of a demographic threat by indicator $K_{i}$

\begin{tabular}{|c|c|c|}
\hline Indicators & $\begin{array}{l}\text { Indicators- } \\
\text { stimulators }\end{array}$ & $\begin{array}{c}\text { Indicators- } \\
\text { de-stimulators }\end{array}$ \\
\hline $\begin{array}{l}P_{K_{i}}-\text { the degree of real strength of a demographic } \\
\text { threat by indicator } K_{i}\end{array}$ & $P_{K_{i}}=\frac{K_{i}^{\text {benchmark }}-K_{i}^{\text {actual }}}{K_{i}^{\text {benchmark }}-K_{i}^{\text {min }}}$ & $P_{K_{i}}^{\prime}=\frac{K_{i}^{\text {actual }}-K_{i}^{\text {benchmark }}}{K_{i}^{\text {max }}-K_{i}^{\text {benchmark }}}$ \\
\hline$S_{K_{i}}$ - the degree of protection by indicator $K_{i}$ & $S_{K_{i}}=\frac{K_{i}^{\text {actual }}-K_{i}^{\min }}{K_{i}^{\text {benchmark }}-K_{i}^{\min }}$ & $S_{K_{i}}^{\prime}=\frac{K_{i}^{\max }-K_{i}^{\text {actual }}}{K_{i}^{\max }-K_{i}^{\text {benchmark }}}$ \\
\hline $\begin{array}{l}G_{K_{i}}-\text { the overall strength of a demographic threat } \\
\text { by indicator } K_{i}\end{array}$ & \multicolumn{2}{|c|}{$G_{K_{i}}=P_{K_{i}} / P_{K_{i}}^{\prime}+S_{K_{i}} / S_{K_{i}}^{\prime}=1$} \\
\hline
\end{tabular}

Analysis of the proposed formulas is given below.

When the actual value reaches the benchmark one, the degree of real force will be equal to 0 , and the degree of protection will be 1 , and when the actual level is equal to the worst value, the degree of real force will make 1 , and the degree of protection will make 0 . There may be an option when the actual value is higher (or lower) than the benchmark one. If it happens, then the following values will be set by a researcher: the degree of real strength is 0 , and the degree of protection is 1 . These indicators' total will make 1, which reflects the overall strength of a demographic threat by indicator $K_{i}$. The word "degree" is used in the indicators' names to show the strength of the real blow and the capacity for protection from it by the scale ranging from 0 to 1 .

The summary characteristic of the degree of real strength $\left(P_{j}^{S U M}\right)$ and the degree of protection $\left(S_{j}^{S U M}\right)$ for a specific demographic threat is estimated by the formula of simple arithmetic mean: $P_{\hat{E}_{i}} / P_{\hat{E}_{i}}^{\prime}$ and $S_{\hat{E}_{i}} / S_{\hat{E}_{i}}^{\prime}$, respectively. The formula of simple geometric mean is not applicable, because some components may take zero values.

The summary estimates of the degree of real strength of four threats $P^{S U M}$ and the degree of protection (the real demographic security) $S^{S U M}$ are also derived by the formulas of simple arithmetic mean:

$$
\begin{aligned}
P^{S U M} & =\frac{\sum_{j=1}^{4} P_{j}^{S U M}}{4}, \\
S^{S U M} & =\frac{\sum_{j=1}^{4} S_{j}^{S U M}}{4} .
\end{aligned}
$$

Value "4" in the denominator is adapted for the Republic of Belarus, to be changed in case of larger or smaller number of threats.

Below we are going to test the proposed method for a comprehensive assessment of demographic security in the Republic of Belarus over time, for 2000, 2015, 2019. Results of the computations are shown in Figure 3

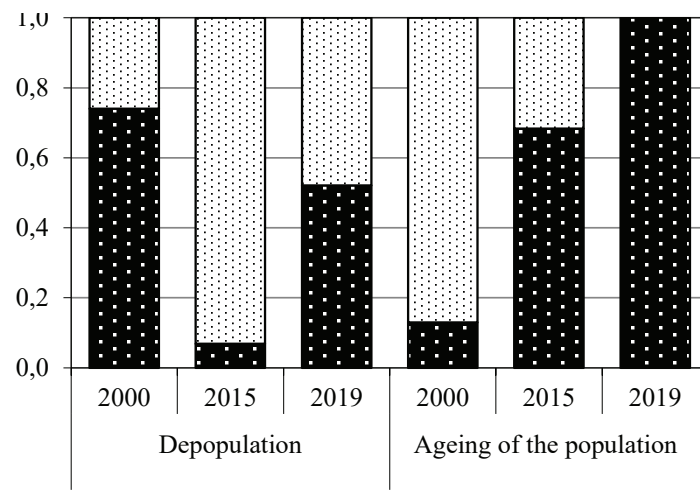

The degree of real strength of a threa

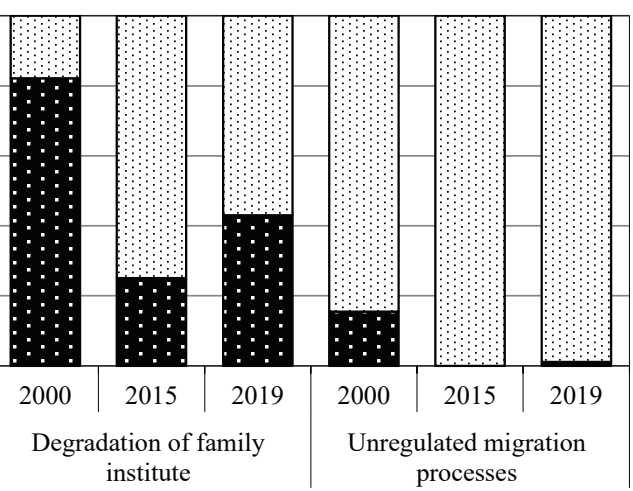

$\square$ The degree of protection

Figure 3. The dynamics of the components of the overall strength of demographic threats in the Republic of Belarus in 2000-2019 
The data in Figure 3 allow us to distinguish between 3 types of the dynamics for two explored variables:

1) the situation was improved with demographic threats of depopulation and degradation of family institutes (the decreased degree of the real strength of the threat and the increased degree of protection) in 2015, and worsened in 2019;

2) the persisting negative dynamics in population ageing, characterized in its final point (2019) by the maximal value of the degree of strength of this threat equal to 1 ;

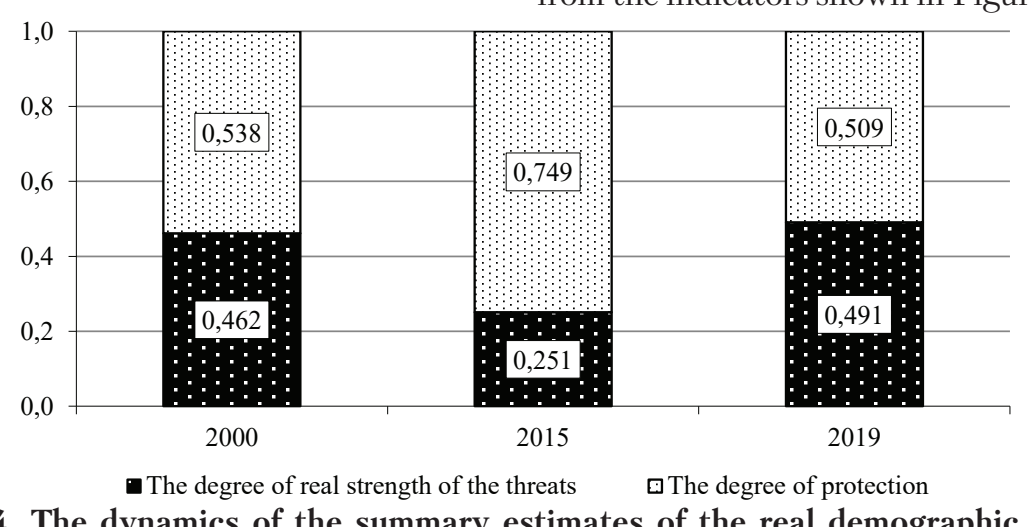

Figure 4. The dynamics of the summary estimates of the real demographic security in the Republic of Belarus in 2000-2019

The dynamics of estimates shown in Figure 4 feature a negative pattern: the increased degree of protection (the real demographic security) in parallel with the decreased degree of the real overall strength of the threats in 2015 compared with 2000, giving way to the decreased degree of the former and the increased degree of the latter in 2019. The major contribution in the significantly grown degree of real strength of the threats in 2019 was made by the maximal estimates of the population ageing indicator.

To sum up, the demographic thaw of 20112016 reached in the Republic of Belarus due to intensive policy measures (the increased birth rate, the decreased mortality rate, the nearly zero natural population growth) gave way to the period of adverse tendencies in demographic processes, mainly because
3) the situation was reverse with unregulated migration processes, with the highest degree of protection reached in 2015 and 2019.

It should be noted that given the net migration of only 35,046 persons in 2016-2019, the expected net migration of 70,000 persons in the period indicated in the Program (2016-2020) is unlikely to be reached. Besides that, the migration activity of the population plummeted in 2020 due to the COVID pandemic.

The summary estimates (see Figure 4) are derived from the indicators shown in Figure 3.

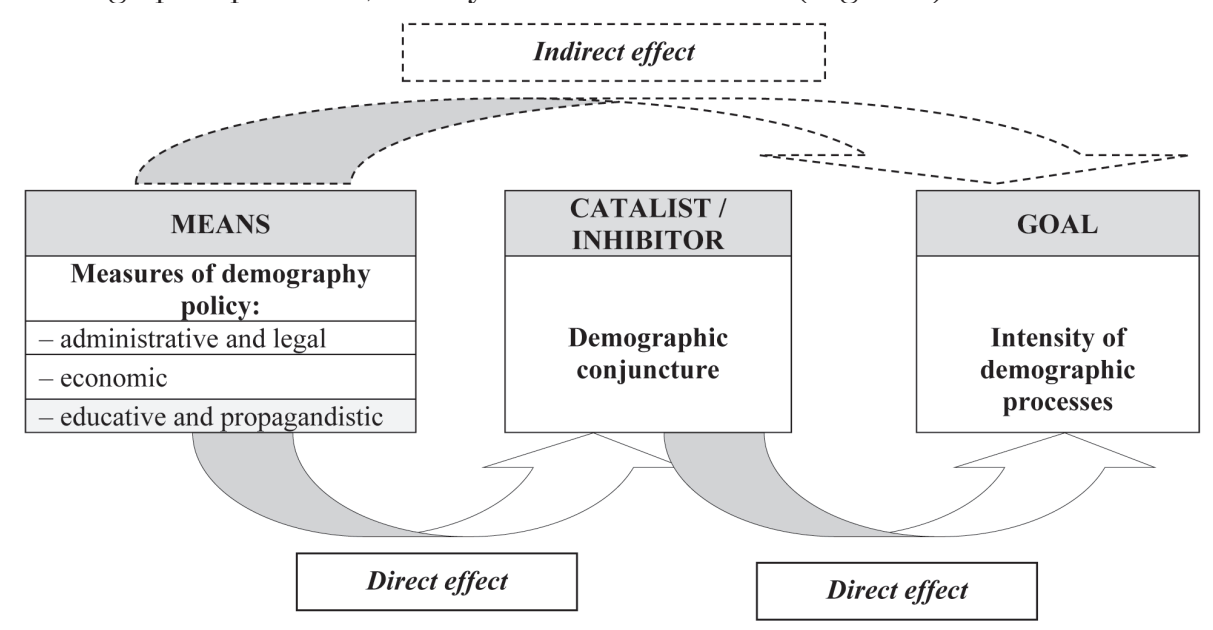

Figure 5. The relationship "demographic policy - demographic conjuncture - intensity of demographic processes" 
As shown in Figure 5, the demographic conjuncture can be either catalyst or inhibitor of the efficiency of demographic policy measures depending on its primary purposes and the plasticity, i. e. the ability to change in a required direction under the government's pressure.

Hence, amodern policy on regulation ofdemographic security will be successful when it is able to trigger longterm reactions of the population in compliance with national demographic interests. This determines the vital importance of change in the demographic outlook of the population through the intensive implementation of educative and propagandistic measures aiming to form a favorable demographic conjuncture. The objective of statistics in this process is to assess the effectiveness of taken measures, e. g. by means of the real demographic security indicator.

The article is published as part of the research project "Elaborate statistical methods for assessment and geospatial visualization of the potential of sustainable innovation-driven development of a region", performed by contract between the Belarussian State Economic University and the Belarussian Republican Foundation for Basic Research No Г19-105 from 02.05.2019.

\section{References}

1. Tikhonova, L. E. (2007). Gosudarstvennoe regulirovanie demograficheskoy bezopasnosti Belarusi [State regulation of demographic security in Belarus]. Minsk: BSU [in Russian].

2. Shakhotko, L. P., \& Privalova, N. N. (2001). Demograficheskaya bezopasnost: sushchnost, zadachi, sistema pokazateley i mekhanizm realizatsii [Demographic security: the essence, objectives, system of indicators and implementation mechanism]. Voprosy statistiki - Statistical issues, 7, 16-21 [in Russian].

3. Epstein, N. D., Egorova, E. A., Karmanov, M. V., Smelov, P. A, \& Karmanov A. M. (2013). Metodologiya analiza demograficheskoy bezopasnosti i migratsii naseleniya [Methodology for the analysis of demographic security and migration of the population]. Moscow: Finansy i statistika [in Russian].

4. Soboleva, S. V., \& Chudaeva, O. V. (2008). Demograficheskaya bezopasnost Rossii i ee regionov: faktory, problemy, indikatory [Demographic safety in Russia and its regions: factors, problems and indicators]. Region: ekonomika i sotsiologiya - Region: Economics and Sociology, 3, 147-167 [in Russian].

5. Grishnova, O. A., \& Kharazishvili, Yu. M. (2019). Demohrafichna bezpeka Ukrainy: indykatory, riven, zahrozy [Demographic security of Ukraine: indicators, level, threats]. Demohrafiia ta sotsialna ekonomika Demography and Social Economy, 2 (36), 65-80. Retrieved from https://dse.org.ua/arhcive/36/5.pdf [in Ukrainian].

6. Aubakirova, Zh. S. (2016). Demograficheskoe razvitie i bezopasnost Kazakhstana (2000-2015 gg.): SWOT-analiz [Demographic development and security of Kazakhstan (2000-2015): SWOT analysis]. Vestnik Natsionalnoy akademii nauk Respubliki Kazakhstan - Bulletin of National Academy of Sciences of The Republic of Kazakhstan, 3, 79-88 [in Russian].

7. Maksakova, L. P. (2020). Demograficheskaya bezopasnost v sovremennom Uzbekistane [Demographic security in modern Uzbekistan]. Chasopys ekonomichnikh reform - Time description of economic reforms, 2 (38), 22-30. DOI: 10.32620/cher.2020.2.03 [in Russian].

8. O demograficheskoy bezopasnosti Respubliki Belarus: Zakon Respubliki Belarus ot 4 yanvarya 2002 g. № 80-Z [On demographic security of the Republic of Belarus. Law of the Republic of Belarus of January 4, 2002, No 80-Z]. mintrud.gov.by. Retrieved from http://mintrud.gov.by/system/extensions/spaw/uploads/ files/o-demograficheskoj-bezopasnosti.pdf [in Russian].

9. Zdorove naroda i demograficheskaya bezopasnost Respubliki Belarus. Gosudarstvennaya programma na 2016-2020 gody: Postanovleniye Soveta Ministrov Respubliki Belarus ot 14.03.2016 № 200 [Public Health and Demographic Security of the Republic of Belarus. State Program for 2016-2020/ Resolution of the Council of Ministers of the Republic of Belarus of March 14, 2016, No 200]. wwere.government.by. Retrieved from http://www.government.by/upload/docs/filecdfof8a76b95e004.PDF [in Russian].

10. Kvasha, A. Ya., \& Melikyan, G. G. (Eds.). (1994). Narodonaselenie: entsiklopedicheskiy slovar [Population: Encyclopedic Dictionary]. Moscow: Bolshaya rossiyskaya entsiklopediya [in Russian]. 


\section{Є. Є. Шарілова,}

кандидат економічних наук, доцент,

доцент кафедри статистики,

Заклад освіти "Білоруський державний економічний університет" (Мінск, Білорусь),

E-mail: sharilovaee@mail.ru

ORCID: https://orcid.org/0000-0002-4862-3624

\section{Комплексна оцінка демографічної безпеки Республіки Білорусь}

Безпека є необхідною складовою життєдіяльності окремих індивідуумів і суспільства загалом. Одним із найважливіших компонентів національної безпеки є демографічна, досягнення якої для Республіки Білорусь означає нейтралізацію таких загроз, як депопуляція, старіння населення, деградація інституту сім'ї та нерегульовані міграційні процеси.

У статті представлена методика комплексної статистичної оцінки демографічної безпеки Республіки Білорусь за 2000-2019 рр. у рамках пропонованого автором дуалістичного підходу до трактування цього поняття, а саме, як реальної і потенційної демографічної безпеки. Реальна демографічна безпека являє собою ступінь захищеності від демографічних загроз в умовах розвитку суспільства, що склалися, і значною мірою визначається відповідністю державної політики демографічним реаліям. Потенційна демографічна безпека є своєрідним еталоном, до якого прагне реальна демографічна безпека.

Запропонована методика комплексної оцінки демографічної безпеки охоплює п'ять послідовних етапів, а саме: формулювання визначення поняття “демографічна безпека”; виявлення демографічних загроз; формування системи показників для комплексної статистичної оцінки демографічної безпеки; оцінка сили впливу демографічних загроз (загальної та реальної); оцінка ступеня захищеності від демографічних загроз (реальної демографічної безпеки).

Структурними компонентами загальної сили впливу демографічних загроз є ступені реальної демографічної безпеки та реальної сили впливу загроз. За період 2000-2019 рр. спостерігалася така тенденція зміни цих величин у Республіці Білорусь: зростання ступеня реальної демографічної безпеки при одночасному зниженні ступеня реальної сили сукупного впливу загроз у 2015 р. порівняно з 2000 р., змінилося зниженням першого показника і збільшенням другого в 2019 р.

Отже, досягнення Республіки Білорусь у галузі демографічної безпеки виявилися короткочасними. Для системної зміни негативних тенденцій потрібне формування сприятливого демографічної кон'юнктури шляхом активного використання виховних і пропагандистських заходів.

Ключові слова: демографічна безпека, демографічна загроза, індикатор, демографічна кон'юнктура, демографічна політика.

Bibliographic description for quoting:

Sharilova, E. E. (2021). E Comprehensive Assessment of the Demographic Security of the Republic of Belarus. Statystyka Ukrainy - Statistics of Ukraine, 1, 85-92. Doi: 10.31767/su.1(92)2021.01.09.

Бібліографічний опис для цитування:

Шарілова Є. Є. Комплексна оцінка демографічної безпеки Республіки Білорусь (публікується англійською мовою). Статистика Украйни. 2021. № 1. С. 85-92. Doi: 10.31767/su.1(92)2021.01.09. 